\title{
Azithromycin effect on multidrug resistant Acinetobacter baumannii biofilm production and composition
}

\author{
Adrián Camacho-Ortiz, ${ }^{*}$ Reynaldo Lara-Medrano, ${ }^{1}$ Michel F. Martínez-Reséndez, ${ }^{1}$ \\ Soraya Mendoza-Olazarán, ${ }^{2}$ Samantha Flores-Treviño² and Elvira Garza-González²

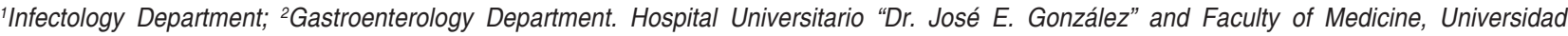 \\ Autónoma de Nuevo León, Monterrey, N. L., Mexico
}

\begin{abstract}
Objectives: To evaluate the effect of azithromycin (AZM) on biofilm formation and composition in multidrug resistant (MDR) Acinetobacter baumannii. Material and methods: Ninety-six A. baumannii isolates were studied. Antimicrobial susceptibility and sub-minimum inhibitory concentration (sub-MIC) were determined by the broth microdilution method. Carbapenemase genes were detected by polymerase chain reaction and clonal diversity by pulsed-field gel electrophoresis (PFGE). Biofilm formation without $A Z M$ and AZM sub-MIC were determined by crystal violet staining. AZM-free biofilm composition and AZM sub-MIC were determined by detachment assays. Results: The selected A. baumannii were MDR; 93.8\% were carbapenem-resistant and 24 were OXA-24-positive. PFGE showed predominance of clones A (53\%), B (34.7\%) and C (12.5\%). Biofilm production at AZM sub-MICs decreased in 53.1\%, increased in $34.7 \%$ and showed no differences in $12.5 \%$ of isolates, in comparison with biofilm production without AZM. Conclusion: AZM sub-MIC can reduce biofilm production in A. baumannii MDR isolates with decreased protein and DNA in the biofilm. Our results may be useful in synergy studies for new therapeutic alternatives.
\end{abstract}

KEY WORDS: Acinetobacter baumannii. Biofilm. Sub-MIC. Biofilm composition.

\section{Efecto de la azitromicina en la producción de biopelículas y la composición de Acinetobacter baumannii resistente a múltiples fármacos}

\section{Resumen}

Objetivos: Evaluar el efecto de la azitromicina (AZM) en la formación y composición de biopelículas en Acinetobacter baumannii resistente a múltiples fármacos (MDR). Material y métodos: Se estudiaron 96 aislamientos de $A$. baumannii. La susceptibilidad antimicrobiana y la concentración inhibitoria submínima (sub-MIC) se determinaron por el método de microdilución del caldo. Los genes carbapenemasa fueron detectados por reacción en cadena de la polimerasa y la diversidad clonal por electroforesis en gel de campos pulsados (PFGE). La formación de biopelículas sin AZM y la subMIC de AZM por tinción de cristal violeta. La composición de la biopelícula sin AZM y la sub-MIC de AZM se determinaron mediante ensayos de desprendimiento. Resultados: Los A. baumannii seleccionados fueron MDR; el 93.8\% resistentes al carbapenem y 24 OXA-24 positivos. El PFGE demostró predominancia en los clones $A$ (53\%), B (34.7\%) y C (12.5\%). La producción de biopelículas en sub-MIC de AZM disminuyó en un $53.1 \%$, aumentó en un $34.7 \%$ y no mostró diferencias en un $12.5 \%$ de los aislamientos, comparado con la producción de biopelículas sin AZM. Conclusión: La sub-MIC de AZM puede reducir la producción de biopelículas en aislamientos de $A$. baumannii MDR

Correspondence:

*Adrián Camacho-Ortiz

E-mail: acamacho_md@yahoo.com
Gac Med Mex. 2021;157:478-483

Contents available at PubMed

www.gacetamedicademexico.com

0016-3813/C 2021 Academia Nacional de Medicina de México, A.C.. Published by Permanyer. This is an open access article under the CC BY-NC-ND license (http://creativecommons.org/licenses/by-nc-nd/4.0/). 
con disminución de proteínas y el ADN en la biopelícula. Nuestros resultados pueden ser útiles en estudios de sinergia para nuevas alternativas terapéuticas.

PALABRAS CLAVE: Acinetobacter baumannii. Biopelícula. Sub-MIC. Composición de biopelícula.

\section{Introduction}

Acinetobacter baumannii is an opportunistic gram-negative coccobacillus associated with outbreaks in intensive care units (ICUs). ${ }^{1}$ This species is related to ventilator-associated pneumonia, bacteremia and surgical site and urinary tract infections, with the former two being the most important due to high morbidity and mortality associated., ${ }^{1,2}$

Antibiotic resistance in $A$. baumannii nosocomial infections is a global health threat, ${ }^{2,3}$ and it is for this reason that this species is on the list of antibiotic-resistant pathogens with global priority for research and development of new and effective antibiotic treatments. ${ }^{4}$

One of $A$. baumannii most important virulence factors is the production of biofilm, which protect the microorganism from the host immune system and from antibiotic treatment. 5,6

Azithromycin (AZM) is a macrolide antibiotic that inhibits bacterial protein synthesis and is indicated in respiratory, urogenital, skin and other bacterial infections mainly caused by gram-positive bacteria species. $^{7}$ In gram-negative species, this antibiotic has been shown to decrease biofilm production, e.g., in Pseudomonas aeruginosa, ${ }^{8}$ Stenotrophomonas maltophilia, ${ }^{9}$ Porphyromonas gingivalis ${ }^{10}$ and Haemophilus influenzae.

According to the literature, the effect of AZM on $A$. baumannii biofilm cells has not been evaluated in detail. Therefore, the purpose of this study was to evaluate the effect of AZM on biofilm formation in $A$. baumannii clinical isolates.

\section{Materials and methods}

\section{Isolates from sites and clinics}

The study was carried out at "Dr. José Eleuterio González" University Hospital, a tertiary care hospital in Monterrey, Mexico. From January to December 2012, a total of 149 A. baumannii clinical isolates were retrieved from ICU patients. Only one isolate per patient was included. $A$. baumannii isolates were identified by MALDI-TOF mass spectrometry (Bruker Daltonics, Bremen, Germany) and intergenic spacer gene amplification by polymerase chain reaction (PCR).$^{11}$ All isolates were stored until their use at -70 ${ }^{\circ} \mathrm{C}$ in Brucella broth containing $15 \%$ glycerol.

\section{Characterization and selection of isolates}

\section{ANTIMICROBIAL SUSCEPTIBILITY}

Antibiotic susceptibility was determined using the broth microdilution method. Examined antibiotics include: amikacin, cefepime, ceftazidime, ciprofloxacin, gentamicin, imipenem, levofloxacin, meropenem, and tobramycin (Sigma-Aldrich, Toluca, Mexico). The results were interpreted according to the Clinical and Laboratory Standards Institute (CLSI) criteria (2018). ${ }^{12}$ Multiple-drug resistance (MDR) was defined as resistance to at least three different classes of antibiotics. ${ }^{13}$ Only MDR isolates were selected in the following assays.

\section{Carbapenemase genes CHARACTERIZATION}

Template DNA was prepared by thermal lysis at 95 ${ }^{\circ} \mathrm{C}$ for $10 \mathrm{~min}$. The carbapenemase genes that encode metallo- $\beta$-lactamases, blaVIM, blalMP and blaNDM, and bla-type D-class OXA-48 carbapenemase (OXA23, OXA-24, OXA-51 and OXA-58) ${ }^{14}$ were typified as previously reported. ${ }^{15-18}$ In the case of positive genes, the PCR products were purified, sequenced by the chain termination method with the Big-Dye Terminator kit (Applied Biosystems, Foster City, CA, USA), and analyzed on an ABIPRrism 3100 genetic analyzer (Applied Biosystems).

\section{Clonal diversity CHARACTERIZATION}

A. baumannii isolates were typified by pulsed-field gel electrophoresis (PFGE). ${ }^{19,20}$ DNA samples of the strains were digested with $10 \mathrm{U}$ of Smal (Takara Bio Inc., Shiga, Japan). PFGE was performed with a CHEF-DRIII instrument (BioRad Laboratories, Hercules, CA, USA), and the banding patterns were 
interpreted using the method described by Seifert et al..$^{17}$ Isolates with $100 \%$ similar band restriction patterns were classified as belonging to the same clone.

\section{BIOFILM PRODUCTION}

Semi-quantitative biofilm production was carried out using the crystal violet staining method, as previously described. ${ }^{21}$ For quantitative analysis, the biofilm index $(\mathrm{BI})$ was determined in order to compensate for growth rate differences. ${ }^{19}$ All isolates were tested in quadruplicate in two independent experiments. Staphylococcus saprophyticus ATCC 15305 (biofilm producer) and Staphylococcus hominis ATCC 27844 (non-biofilm producer) were used as control organisms. The cutoffs proposed by Christensen et al. were used to classify the isolates. Only strongly biofilm-producing isolates (optical density $[O D] \geq 0.24$ ) were selected in the ensuing assays.

\section{AZM SUB-MINIMAL INHIBITORY CONCENTRATIONS}

AZM (Sigma-Aldrich, Toluca, Mexico) minimal inhibitory concentrations (MIC) were determined for eight randomly selected $A$. baumannii isolates. Subsequently, double dilutions from 0.125 to $8.8 \mu \mathrm{g} / \mathrm{mL}$ were prepared and a 24-h culture was used as inoculum. After incubation at $37^{\circ} \mathrm{C}$, optical density was measured at $600 \mathrm{~nm}$ (OD: 600). AZM sub-minimal inhibitory concentrations (sub-MIC) were defined as the concentration at which inhibited growth was observed.

\section{EFFECT OF AZM SUB-MIC ON BIOFLLM PRODUCTION AND COMPOSITION}

For the analysis of AZM sub-MIC impact on biofilm production, each mature biofilm was cultivated in tryptic soy broth supplemented with $1 \%$ glucose without AZM and with an AZM sub-MIC for $24 \mathrm{~h}$. The BI was determined as previously described. ${ }^{19}$ For the analysis of AZM sub-MIC on biofilm composition, detachment assays were performed using sodium meta-periodate (NalO4) to degrade $\beta$-1, 6-link polysaccharides, proteinase $\mathrm{K}$ to degrade proteins, and DNase I to degrade DNA, as previously described. ${ }^{22}$ Percent detachment was calculated by the mean difference between treated and untreated wells. The assays were performed without $A Z M$ and with an AZM sub-MIC.

\section{Statistical anALYSES}

Data were analyzed with SPSS statistical program, version 20.0 (IBM Corporation, Somers, NY, USA). PFGE banding patterns similarity coefficients were generated from a similarity matrix calculated with the Jaccard coefficient. Descriptive analysis was used for quantitative variables, and qualitative variables were expressed as proportions. Student's t-test was used to compare the paired samples (biofilm index and biofilm detachment percentage). A p-value $<0.05$ was considered statistically significant.

\section{Declaration of ethics}

The study was carried out with approval of the Ethics Committee of the Faculty of Medicine of Autonomous University of Nuevo León (approval no. PII5-0243). Given that patient information was anonymous, only microbiological data were analyzed. Therefore, the local ethics committee did not mandate informed consent.

\section{Results}

\section{Clinical isolates, biofilm production and antimicrobial susceptibility}

Of a total of $149 \mathrm{~A}$. baumannii strains collected at the ICU, 140 (97\%) were found to be strong biofilm producers, and the remaining $9(3 \%)$ were weak producers.

All isolates were resistant to ciprofloxacin, gentamicin and ceftazidime, and $99 \%$ were resistant to tobramycin and levofloxacin. Of all isolates, $93.8 \%$ were resistant to carbapenems (meropenem and imipenem), and almost $70 \%$ were resistant to cefepime, with $22.9 \%$.

We selected 96 biofilm-producing MDR $A$. baumannii clinical isolates for further analysis; $80 \%$ were obtained from respiratory samples and $12.5 \%$ from blood cultures, while the rest were obtained from other specimens.

\section{Characterization of carbapenemase genes and clonal diversity}

All 96 selected $A$. baumannii isolates were positive for the OXA-type carbapenemase gene, with OXA-51 and OXA-24 being the most common with $100 \%$ and 
$96 \%$, respectively; none of the isolates encoded for the blaVIM, blalMP and blaNDM genes.

Twelve PFGE patterns (A-M) were detected, with $51(53 \%)$ being identified as clone A, $15(15 \%)$ as clone B and $9(9 \%)$ as clone $\mathrm{C}$.

\section{Effect of azithromycin on biofilm production and composition}

The selected sub-MIC was $0.125 \mu \mathrm{g} / \mathrm{mL}$. When all 96 isolates were evaluated, BI without AZM was 1.737 , and when exposed to AZM sub-MIC, BI was 1.488 .

When we compared the $B I$ without AZM and at AZM sub-MIC, BI distribution was heterogeneous, with $53.1 \%$ revealing a BI decrease $(p<0.0001), 34.7 \%$ demonstrating a Bl increase $(p<0.0001)$, and $12.5 \%$ not showing any difference (Fig. 1).

Biofilm in the absence of AZM was composed mainly of proteins and DNA (detachment with proteinase $\mathrm{K}, 88 \%$, and DNase I, $87 \%$ ), and carbohydrates (detachment with meta-periodate, $30 \%$ ).

Biofilm at AZM sub-MIC showed similar results (detachment with proteinase K, 79\%; DNase I, $77 \%$; and meta-periodate, $25 \%$ ). The proportion of proteins in DNA was lower in biofilm with AZM sub-MIC than in biofilm without AZM $(p<0.05)$ (Fig. 2).

\section{Discussion}

One of $A$. baumannii most important virulence factors is biofilm production, and AZM has been shown to inhibit biofilm formation in several bacterial species. Therefore, we evaluated the effect of AZM on MDR A. baumannii clinical isolates and found that, when exposed to AZM sub-MIC, biofilm production decreases with the reduction of the proportion of proteins in DNA. AZM has been reported to significantly decrease biofilm production when $A$. baumannii strains with mild and moderate biofilm and a sublayer of $1 \mu \mathrm{g} / \mathrm{mL}$ are used. ${ }^{23}$ In this study, we defined $0.125 \mu \mathrm{g} / \mathrm{mL}$ as AZM sub-MIC, and only strongly biofilm-producing strains were included. The difference observed in AZM sub-MIC values may be due to the differences in the clinical strains used for this study, especially due to the different biofilm production levels. Exposure of bacteria to antibiotics sub-MICs under clinical conditions is highly likely. Some examples are: a) due to drug interaction, b) due to absorption deficiencies or c) immediately before the following doses. For this reason, it is important to note that the $0.125-\mu \mathrm{g} / \mathrm{mL}$ concentration used in our assays is below AZM peak serum level when used at standard intravenous doses (peak serum level of $3.6 \mu \mathrm{g} / \mathrm{mL}$ with a dose of $500 \mathrm{mg} \mathrm{IV} \mathrm{q24h);24}$ therefore, this concentration can have an effect in vivo.

According to the CLSI, a sub-MIC concentration is the concentration of an antimicrobial agent that is not active at bacterial growth but that is still active at altering the biochemistry and shape of bacteria in vitro and in vivo, thus reducing bacterial virulence. Although these sub-MIC levels do not kill bacteria, they are able to modify their characteristics and, according to our results, the composition of the biofilm is altered, with a lower proportion of proteins. This can have an impact on important bacterial cellular functions or on virulence.

The biofilm without AZM is mainly composed of proteins and DNA, whereas the biofilm with AZM subMIC showed a lower proportion of proteins, which may reflect AZM action on protein synthesis. It should be pointed out that the strains continued to be strong biofilm producers even when exposed to AZM sub-MIC.

In our institution, $A$. baumannii clonal distribution has been reported throughout six years and, according to this study, there is high clonality in this population. ${ }^{25}$

For this study, half the $A$. baumannii isolates were grouped into one predominant clone $(A)$, and the remaining isolates were classified into 11 different patterns. Thus, the analyzed sample is heterogeneous and does not correspond to the study of an isolated clone.

The OXA-type carbapenemases investigated in our study are the most prevalent enzymes associated with carbapenem resistance in $A$. baumannii. Although OXA-23 is distributed throughout the world, none of our strains tested positive for this gene; ${ }^{26}$ conversely, almost all isolates were found to be OXA-24. This genotype has been described in outbreaks that caused bacteremia cases in which the strains remained susceptible only to colistin and tigecycline, ${ }^{27}$ and has been previously reported in our institution. ${ }^{25}$ AZM activity in the production and composition of biofilms can have a profound effect that offers new therapeutic alternatives, especially for these MDR strains; to this end, synergy studies with AZM and those antibiotics recommended for the treatment of $A$. baumannii infections, including quinolones and carbapenems, may offer new therapeutic alternatives. 


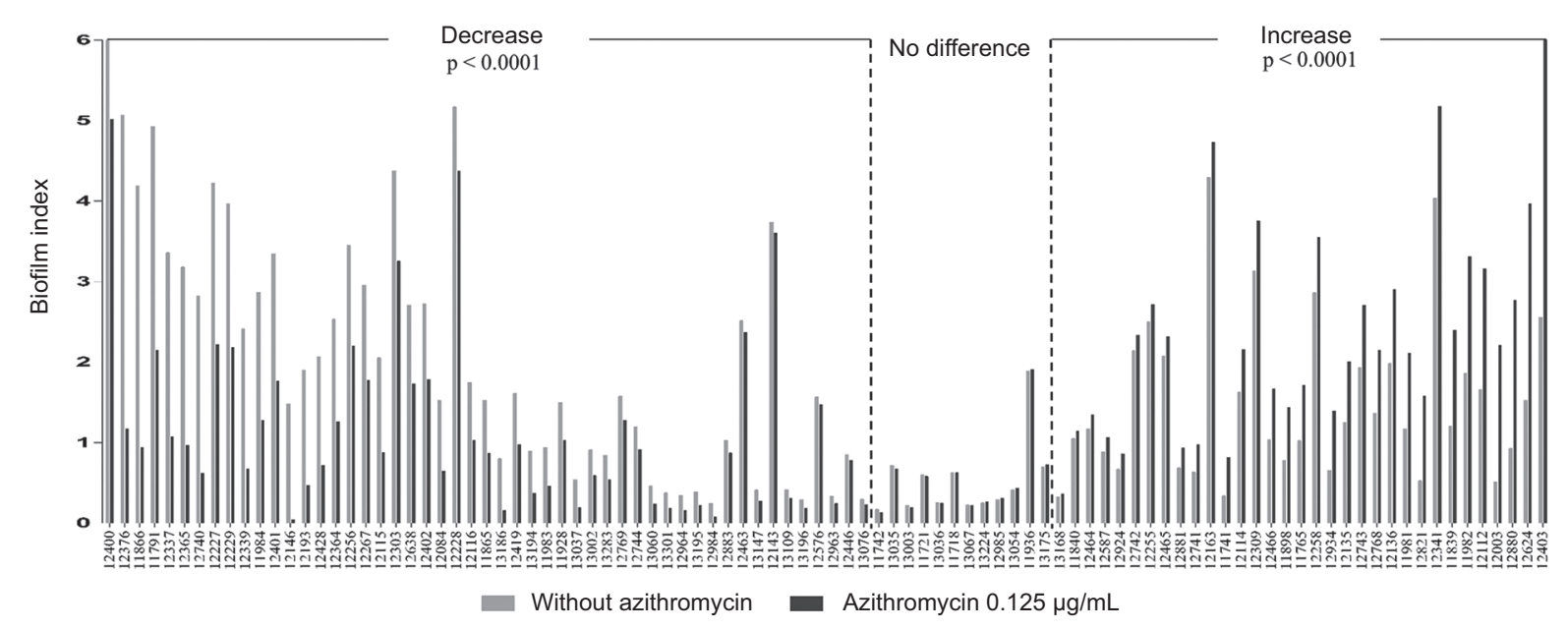

Figure 1. Azithromycin effect on biofilm index.

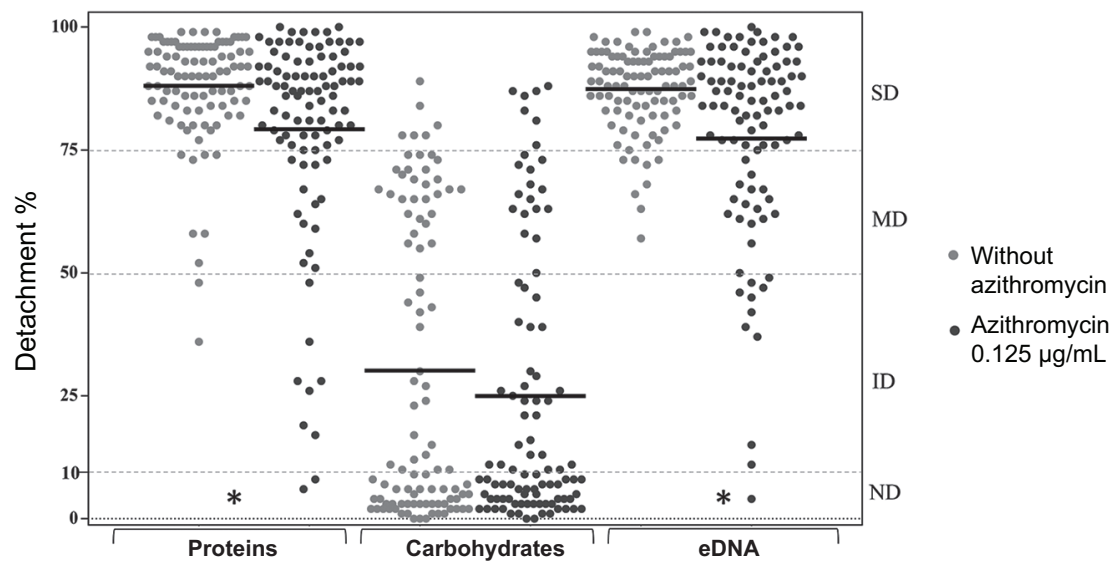

Figure 2. Azithromycin effect on biofilm composition.

${ }^{*} p<0.001$.

SD: strong detachment; MD: moderate detachment; ID: intermediate detachment; ND: no detachment.

In conclusion, an AZM sub-MIC can reduce biofilm production in MDR $A$. baumannii isolates with a decrease of proteins and DNA in the biofilm. Our results are the basis for synergy studies that can offer new therapeutic alternatives.

\section{Funding}

The present study received no sponsoring; it was carried out with the institution's own resources.

\section{Conflict of interests}

The authors declare that there are no conflicts of interest.

\section{Ethical disclosures}

Protection of human and animal subjects. The authors declare that no experiments were performed on humans or animals for this research.

Confidentiality of data. The authors declare that they have followed the protocols of their work center on the publication of patient data.

Right to privacy and informed consent. The authors declare that no patient data appear in this article.

\section{References}

1. Custovic A, Smajlovic J, Tihic N, Hadzic S, Ahmetagic S, Hadzagic H. Epidemiological monitoring of nosocomial infections caused by Acinetobacter baumannii. Med Arch. 2014; 68:402-6. 
2. Dijkshoorn L, Nemec A, Seifert H. An increasing threat in hospitals: multidrug- resistant Acinetobacter baumannii. Nat Rev Microbiol. 2007;5:939-51.

3. Peleg AY, Seifert H, Paterson DL. Acinetobacter baumannii: emergence of a successful pathogen. Clin Microbiol Rew. 2008;21:538-82.

4. World Health Organization. 2017. Global Priority List of Antibiotic-Resistant Bacteria to Guide Research, Discovery, and Development of New Antibiotics [Internet]. World Health Organization [viewed: December 10 , 2018]. Available at: http://www.who.int/medicines/publications/WHOPPL-Short_Summary_25Feb-ET_NM_WHO.pdf

5. Longo F, Vuotto C, Donelli G. Biofilm formation in Acinetobacter baumannii. New Microbiol. 2014;37:119-27.

6. Rodriguez-Bano J, Marti S, Soto S, Fernandez-Cuenca F, Cisneros JM, Pachón J, et al. Biofilm formation in Acinetobacter baumannii: associated features and clinical implications. Clin Microbiol Infect. 2008:14:276-8.

7. Parnham MJ, Erakovic Haber V, Giamarellos-Bourboulis EJ, Perletti G, Verleden GM, Vos R. Azithromycin: mechanisms of action and their relevance for clinical applications. Pharmacol Ther. 2014;143:225-45.

8. Imperi F, Leoni L, Visca P. Antivirulence activity of azithromycin in Pseudomonas aeruginosa. Front Microbiol. 2014;5:178.

9. Wang A, Wang Q, Kudinha T, Xiao S, Zhuo C. Effects of fluoroquinolones and azithromycin on biofilm formation of Stenotrophomonas maltophilia. Sci Rep. 2016;6:29701.

10. Maezono H, Noiri Y, Asahi Y, Yamaguchi M, Yamamoto R, Izutani N, et al. Antibiofilm effects of azithromycin and erythromycin on Porphyromonas gingivalis. Antimicrob Agents Chemother. 2011;55:5887-92

11. Chen TL, Siu LK, Wu RC, Shaio MF, Huang LY, Fung CP, et al. Comparison of one-tube multiplex PCR, automated ribotyping and intergenic spacer (ITS) sequencing for rapid identification of Acinetobacter baumannii. Clin Microbiol Infect. 2007;13:801-6.

12. Clinical and Laboratory Standards Institute (CLSI). Performance Standards for Antimicrobial Susceptibility Testing. $26^{\text {th }}$ ed. CLSI supplement M100S. Wayne, PA, USA: Clinical and Laboratory Standards Institute; 2016.

13. Magiorakos AP, Srinivasan A, Carey RB, Carmeli Y, Falagas ME, Giske $\mathrm{CG}$, et al. Multidrug-resistant, extensively drug-resistant and pandrug-resistant bacteria: an international expert proposal for interim standard definitions for acquired resistance. Clin Microbiol Infect. 2012;18:268-81.

14. Dortet L, Poirel L, Nordmann P. Worldwide dissemination of the NDM-type carbapenemases in Gram-negative bacteria. BioMed Res Int. 2014;2014:249856

15. Baroud M, Dandache I, Araj GF, Wakim R, Kanj S, Kanafani Z, et al. Underlying mechanisms of carbapenem resistance in extended-spectrum beta-lactamase-producing Klebsiella pneumoniae and Escherichia coli isolates at a tertiary care centre in Lebanon: role of OXA-48 and NDM-1 carbapenemases. Int J Antimicrob Agents. 2013;41:75-9.
16. Ellington MJ, Kistler J, Livermore DM, Woodford N. Multiplex PCR for rapid detection of genes encoding acquired metallo-beta-lactamases. J Antimicrob Chemother. 2007:59:321-2.

17. Nordmann P, Poirel L. Emerging carbapenemases in Gram-negative aerobes. Clin Microbiol Infect. 2002:8:321-31.

18. Woodford N, Ellington MJ, Coelho JM, Turton JF, Ward ME, Brown S, et al. Multiplex PCR for genes encoding prevalent OXA carbapenemases in Acinetobacter spp. Int J Antimicrob Agents. 2006;27:351-3.

19. Mendoza-Olazarán S, Camacho-Ortiz A, Martínez-Reséndez MF, Llaca-Díaz JM, Pérez-Rodríguez E, Garza-González E. Influence of whole-body washing of critically ill patients with chlorhexidine on Acinetobacter baumannii isolates. Am J Infect Control. 2014;42:874-8.

20. Bou G, Cervero G, Domínguez MA, Quereda C, Martínez-Beltrán J. PCR-based DNA fingerprinting (REP-PCR, AP-PCR) and pulsed-field gel electrophoresis characterization of a nosocomial outbreak caused by imipenem- and meropenem-resistant Acinetobacter baumannii. Clin Microbiol Infect. 2000;6:635-43.

21. Christensen GD, Simpson WA, Younger JJ, Baddour LM, Barrett FF Melton DM, et al. Adherence of coagulase-negative staphylococci to plastic tissue culture plates: a quantitative model for the adherence of staphylococci to medical devices. J Clin Microbiol. 1985;22:996-1006.

22. Mendoza-Olazaran S, Morfin-Otero R, Villarreal-Trevino L, Rodriguez-Noriega E, Llaca-Diaz J, Camacho-Ortiz A, et al. Antibiotic susceptibility of biofilm cells and molecular characterisation of Staphylococcus hominis isolates from blood. PLoS One. 2015;10: e0144684.

23. Bogdan M, Drenjancevic D, Harsanji Drenjancevic I, Bedenic B, Zujic Atalic $\mathrm{V}$, talapko $\mathrm{J}$, et al. In vitro effect of subminimal inhibitory concentrations of antibiotics on the biofilm formation ability of Acinetobacter baumannii clinical isolates. J Chemother. 2018;30:16-24.

24. Rapp RP. Pharmacokinetics and pharmacodynamics of intravenous and oral azithromycin: enhanced tissue activity and minimal drug interactions. Ann Pharmacother.1998;32:785-93.

25. Bocanegra-lbarias P, Peña-López C, Camacho-Ortiz A, Llaca-Díaz J, Silva-Sánchez J, Barrios H, et al. Genetic characterisation of drug resistance and clonal dynamics of Acinetobacter baumannii in a hospital setting in Mexico. Int J Antimicrob Agents. 2015;45:309-13.

26. Lee CR, Lee JH, Park M, Park KS, Bae IK, Kim YB, et al. Biology of Acinetobacter baumannii: Pathogenesis, antibiotic resistance mechanis$\mathrm{ms}$, and prospective treatment options. Front Cell Infect Microbiol. 2017;7:55.

27. Acosta J, Merino M, Viedma E, Poza M, Sanz F, Otero JR, et al. Multidrug-resistant Acinetobacter baumannii Harboring OXA-24 carbapenemase, Spain. Emerg Infect Dis. 2011;17:1064-7. 